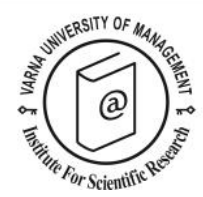

\title{
Complying with digital transformation in online booking through experiential values of generation $\mathrm{Z}$
}

\author{
Aikaterini Stavrianea ${ }^{1}$ and Irene (Eirini) Kamenidou ${ }^{2 *}$
}

\footnotetext{
${ }^{1}$ Department of Communication and Media Studies, National and Kapodistrian University of Athens, Greece. Email: aikstavria@media.uoa.gr

${ }^{2}$ Department of Management Science and Technology, International Hellenic University School of Business and Economics, Kavala Campus, 65404 Greece, E-mail: rkam@mst.ihu.gr
}

${ }^{*}$ Corresponding author

\begin{abstract}
This paper offers insights into experiential values and online accommodation booking in the digital transformation era of the tourism sector in relation to the Greek Generation Z cohort. More specifically, the role of experiential values, attitudes, and involvement as well as their impact on patronage intentions of the Generation $\mathrm{Z}$ cohort are investigated. Quantitative research conducted with an online questionnaire yielded a sample of 970 Generation Zers' responses. Using the Structural Equation Model via the AMOS statistical package, six hypotheses were tested. Results have revealed that the construct of experiential values positively impacts directly on patronage intentions, attitudes towards the e-booking platform, and customer involvement. Additionally, Generation Z members' attitudes towards the e-booking platform and involvement with the platform impacts patronage intentions. Furthermore, involvement with the e-booking platform has a negative effect on consumers' attitudes towards the platform. Detailed discussion of results and further implications is also provided.
\end{abstract}

Key words: Digital transformation; Tourism; Experiential Values; Generation Z Cohort; Marketing; Digital Communication

Citation: Stavrianea, A. and Kamenidou, I. (2022). Complying with digital transformation in online booking through experiential values of generation Z. European Journal of Tourism Research 30, 3003. 


\section{Introduction}

Previous research advocates that the use of technology has affected every aspect of industry, business, and company operations, since retailers are continuously converting their services to digital channels (Hallikainen et al., 2018). The tourism industry belongs to the sectors most profoundly affected by technological advances, mainly because it is highly service oriented (Osei et al., 2020; Pabel, 2020). Thus, it is characterized by harsh competition, and struggles to decrease service costs (Vasko \& Abraham, 2015). As a result, the tourism industry depends heavily on online marketing communication, and subsequently on communication technologies. This is clearly indicated by researchers who point out that in the late '9os, the diffusion of the internet initiated the transformation of the tourism-related distribution channels (Buhalis and Amaranggana, 2013; Chatzigeorgiou \& Christou, 2020; Papathanassis, 2017; Li et al., 2017) On the other hand, consumers today are also more knowledgeable and experienced in terms of technology, being a critical stakeholder of the digital market (Ruiz-Gomez \& Navio-Marco, 2018; Vaško \& Abrhám, 2015), as they become increasingly aware of, and adopt, the digital channels for product and service purchase (Chatzigeorgiou \& Christou, 2020; Vendrell-Herrero et al., 2017). In particular, the rapid growth of the Airbnb online business model has had important consequences for the hospitality industry, tourism destinations and consumers (Chiappa et al., 2020; Dogru et al., 2020; Priporas et al., 2017a,b; Zervas et al., 2017). Therefore, the use of technology has affected considerably the demand and the supply of tourism products (Buhalis, 1998). More specifically, in the tourism industry, web-based materials constitute the most prominent source of information to travel planners (Abou-Shouk \& Khalifa, 2017), with the use of e-booking or online booking platforms (OBP). The OBP are the most used ones by prospective tourists (Sánchez-Lozano et al., 2020), representing an easy and efficient way for travel organization (Bigne et al., 2020; Ristova \& Maglovski, 2018). This digital transformation in the sector of tourism contributed to significant changes, increased competition, and has given rise to new opportunities. Lee et al. (2014) postulate that digital technology has truly revolutionized modern societies. According to Henriette et al. (2016), digital transformation exhibits two main dimensions, namely the digital technologies and the user/consumer experience. The latter is a multidimensional concept with experiential components, and it generates value for the consumer that originates from his/her interactions with an "object" (Gentile et al. 2007; Holbrook, 2006). Holbrook (1994, p. 27) characterizes customer value as "an interactive relativistic preference experience," where "such interactive relativistic preferences form the essence of the consumption experiences" (Holbrook, 2006, p. 715).

There is an abundance of previous studies that refer to the tourism and travel sector in association with consumer behaviour (Cohen et al. 2014; Manyiwa et al., 2018; Moutinho, 1987; Stiakakis \& Vlachopoulou, 2017), and a plethora of studies referring to the inclusion of digitalization in the sector of tourism (Kayumovich, 2020; Pierdicca et al., 2019; Xiang et al., 2015; Buhalis \& Law, 2008). Many scholars concentrate on smart tourism (Buhalis and Amaranggana, 2013; Gretzel et al., 2015; Hassannia et al., 2019; Wan, 2018), or tourism and digital transformation (Härting et al., 2017; Lam and Law, 2019; Zsarnoczky, 2018). Moreover, a significant number of published papers focus on online booking [OB] (Guillet et al, 2020; Huang et al., 2020; Sánchez-Lozano et al., 2020; Li et al., 2017; Zhao et al., 2015), on customer experience from online and mobile retailing (Fan et al., 2020; Li et al., 2020; Pantano \& Priporas, 2016; Rose et al., 2012; Verhoef et al., 2009), or on experiential values (EV) and the use of internet (Alias et al. 2016; Fiore et al., 2005; Lee, 2005; Saidon and Musa, 2017; Shobeiri et al., 2015; Stavrianea et al., 2019; Tilokskulchai \& Soontayatron, 2017). However, these are merely few indicative topics of the general topics regarding technology and the tourism sector that have been explored in the academic research. 
Although numerous studies examine the association that holds among the tourism industry and consumers' behaviour, studies combining consumer EV and OB in the digital transformation era of tourism are rather scarce. Research findings have demonstrated that the interrelation amongst EV and OB had been understudied, with only a handful of articles compiled on the subject (eg., Abdullah et al., 2016; Choi, 2015; Stavrianea et al., 2019).

Having in mind the aforementioned, the present paper seeks to explore customer EV during information search and purchase via accommodation OBP. In addition, the role of EV, attitudes, and involvement, and their effects on patronage intentions of the Generation $\mathrm{Z}$ cohort (Gen $\mathrm{Z}$ ) is extensively under- investigated. Since this paper examines EV within digital transformation in the tourism sector, the targeted group consists of people aged 18-23 years old, i.e., individuals that belong to the Gen $\mathrm{Z}$ cohort. Members of this generation, the also-called digital natives have been raised in a technological environment, being keen on technology, and never experienced lack of internet and computers in their life (Kamenidou et al., 2020a; Reinikainen, 2020). Thus, this research aims to address the subsequent literature gaps:

1. The targeted group for participation in the current survey includes Greek consumers that are members of the Gen Z cohort, thus, individuals that were born in the time period between 1995 and 2009 (Williams \& Page, 2011). The research on this generational cohort regarding tourism is novel, comparatively extremely limited, thus, leaving space for further exploration.

2. It focuses on EV from online accommodation booking (OAB), which is an understudied topic, since only three relevant papers have been pointed out (i.e., Abdullah et al., 2016; Choi, 2015; Stavrianea et al., 2019).

3. While three studies have been encountered on EV from OAB, as far as we know, only one previous combination with the Gen $\mathrm{Z}$ cohort exists (i.e., the work of Stavrianea et al., 2019). Consequently, this framework offers foundations for more research on the topic since this group is regarded as essential for studying purposes, constituting the youngest adult-consumer group with limited research in the marketing field (Kamenidou et al., 2018; Priporas et al., 2017C).

\section{Literature Review}

EV form an area that increasingly attracts the interest of academic researchers (Mathwick et al., 2001; Pine \& Gillmore 1999; Shobeiri et al. 2018; Stavrianea et al., 2019). EV relate to the pleasurable consumption experiences that can be offered to customers through the addition of experiential benefits to product and services (Ahn et al. 2019; Shobeiri et al., 2013). In that way, brands can respond to the modern consumer needs for superior value, and experience rather than commodity products (Brakus et al., 2009; Kavoura \& Stavrianea, 2016; Keng et al., 2007; Shobeiri et al. 2018).

EV can have both extrinsic and intrinsic elements, with the intrinsic emphasizing the recognition of the experience itself (Hollbrook, 1994; Mano \& Oliver, 1993). According to Holbrook (1994) values that are obtained by experience can be distinguished into two dimensions: i.e., the intrinsic versus extrinsic values on the first axis, and the active versus reactive sources of value on the second axis. Mathwick et al. (2001) proposed four aspects of EV; these dimensions consist of aesthetics (Aes), playfulness (Pl), service excellence (SE), as well as consumer return on investment (CROI). Aes refers to the aspect of consumption experience that relates to the ocular attraction, like the layout and patterns, or, for instance, graphics and pictures for the online experience (Holbrook, 1994; Mathwick et al., 2001). The $\mathrm{Pl}$ nuance of EV relates to the inherent pleasure that a consumer derives from the experiences that offer an escape from everyday life and responsibilities (Mathwick et al., 2001; Unger \& Kernan 1983). SE, on the other hand, is associated with the evaluation that the consumer makes about the degree in which 
the provider managed to deliver a standard of quality and expertise (Zeithmal, 1988). Lastly, CROI interrelates with the utility, in other words, the consumer's gain from the experience, compared to his/her investment (Mathwick et al., 2001).

Along these lines, Ahn et al. (2019) explored the importance of EV on co-creation behavior; Abdullah et al. (2016) studied the perception of website interactivity and value on loyalty, while Choi (2015) examined the influence of a website's EV on satisfaction and loyalty. Similarly, Shobeiri et al. (2014) explored the impact of EV website involvement and perceived e-retailers assistive intention. In the context of OBP, limited scholarly work has exploited the area of EV. Keng et al. (2007) suggested that EV impact behavioral intentions in the context of shopping malls in Taiwan, whereas Mathwick et al. (2001) studied the role of EV on future patronage intentions for catalog shoppers. Table 1 shows a synopsis of the most relevant research on the topic.

Table 1. A synopsis of empirical studies on EV-marketing

\begin{tabular}{|c|c|c|c|}
\hline $\begin{array}{l}\text { Authors/ } \\
\text { Year }\end{array}$ & Purpose & Industry & Findings \\
\hline $\begin{array}{l}\text { Ahn et al. } \\
(2019)\end{array}$ & $\begin{array}{l}\text { Examine the importance } \\
\text { of EV on co-creation } \\
\text { behaviour. }\end{array}$ & $\begin{array}{l}\text { Integrated resort } \\
\text { customers }\end{array}$ & $\begin{array}{l}\text { PL, CROI and SE influence co- } \\
\text { creation behaviour. }\end{array}$ \\
\hline $\begin{array}{l}\text { Brakus et al. } \\
(2009)\end{array}$ & $\begin{array}{l}\text { Create a scale for } \\
\text { measuring brand } \\
\text { experience. }\end{array}$ & $\begin{array}{l}\text { Different } \\
\text { industries }\end{array}$ & $\begin{array}{l}\text { Brand experience directly impacts } \\
\text { satisfaction and loyalty and } \\
\text { indirectly through brand } \\
\text { personality. }\end{array}$ \\
\hline Choi (2015) & $\begin{array}{l}\text { Empirically explored the } \\
\text { associations among EV, } \\
\text { satisfaction, and loyalty in } \\
\text { the context of travel } \\
\text { websites. }\end{array}$ & $\begin{array}{l}\text { Tourism } \\
\text { websites }\end{array}$ & $\begin{array}{l}\text { CROI and SE are linked with } \\
\text { satisfaction, which in turns, affects } \\
\text { in a direct way loyalty. }\end{array}$ \\
\hline $\begin{array}{l}\text { Keng et al. } \\
(2007)\end{array}$ & $\begin{array}{l}\text { Investigate the relations } \\
\text { between } \mathrm{EV} \text {, service } \\
\text { encounters and } \\
\text { behavioural intentions of } \\
\text { shopping malls customers. }\end{array}$ & Shopping Malls & $\begin{array}{l}\text { Personal interaction encounters } \\
\text { influence efficiency and excellence } \\
\text { value. } \\
\text { Physical environment encounters } \\
\text { have an impact on Pl and Aes. } \\
\text { EV affects behavioural intentions. }\end{array}$ \\
\hline $\begin{array}{l}\text { Lee and } \\
\text { Overby (2004) }\end{array}$ & $\begin{array}{l}\text { Explore the effect of } \\
\text { shopping values on } \\
\text { satisfaction and loyalty. }\end{array}$ & $\begin{array}{l}\text { Internet } \\
\text { shopping }\end{array}$ & $\begin{array}{l}\text { Utilitarian and EV positively } \\
\text { influence satisfaction. The latter has } \\
\text { an impact on loyalty. }\end{array}$ \\
\hline $\begin{array}{l}\text { Mathwick et al. } \\
\text { (2001) }\end{array}$ & $\begin{array}{l}\text { Evolve and test a scale for } \\
\text { measuring EV that can be } \\
\text { employed in retail } \\
\text { shopping. }\end{array}$ & $\begin{array}{l}\text { Online and } \\
\text { Catalog } \\
\text { shopping }\end{array}$ & $\begin{array}{l}\text { In the context of online shopping, } \\
\text { perceived CROI is significantly } \\
\text { linked to the online shopping } \\
\text { preference. } \\
\text { Catalog shopping is based upon a } \\
\text { broad range of EV sources. It } \\
\text { entertains, is visually appealing, } \\
\text { efficient, and affordable. }\end{array}$ \\
\hline
\end{tabular}




\begin{tabular}{|c|c|c|c|}
\hline $\begin{array}{l}\text { Authors/ } \\
\text { Year }\end{array}$ & Purpose & Industry & Findings \\
\hline $\begin{array}{l}\text { Shobeiri et al. } \\
(2013)\end{array}$ & $\begin{array}{l}\text { Investigate the way in } \\
\text { which experiential } \\
\text { marketing assists the } \\
\text { online retailing to improve } \\
\text { its brand image. }\end{array}$ & Online Retailing & $\begin{array}{l}\text { EV differ regarding their importance } \\
\text { in forming an e-retailer's website } \\
\text { personality. } \\
\text { Only SE was found to influence all } \\
\text { five aspects of a website's } \\
\text { personality. } \\
\text { The five aspects of the website } \\
\text { personality could be ameliorated by } \\
\text { the provision of certain EV. }\end{array}$ \\
\hline $\begin{array}{l}\text { Shobeiri et al. } \\
(2014)\end{array}$ & $\begin{array}{l}\text { Examine the degree to } \\
\text { which EV could } \\
\text { ameliorate the reactions of } \\
\text { the customers towards an } \\
\text { e-retailer's website. }\end{array}$ & Online Shopping & $\begin{array}{l}\text { Extrinsic/utilitarian values - } \\
\text { including CROI and SE - influence } \\
\text { in a greater extent the enhancement } \\
\text { of perceived assistive image and } \\
\text { involvement with the website. } \\
\text { Customers appreciate the } \\
\text { experiential dimensions of the } \\
\text { website, since they carry significant } \\
\text { messages regarding the e-retailer's } \\
\text { customer-centric orientation. }\end{array}$ \\
\hline $\begin{array}{l}\text { Shobeiri et al. } \\
(2018)\end{array}$ & $\begin{array}{l}\text { Examine the differences } \\
\text { regarding the influence of } \\
\text { EV from online retailing } \\
\text { amongst North American } \\
\text { and Chinese customers. }\end{array}$ & Online Retailing & $\begin{array}{l}\text { The impact of EV on involvement } \\
\text { with the website and loyalty is } \\
\text { higher for North Americans than for } \\
\text { Chinese visitors. } \\
\text { The influence of involvement on } \\
\text { attitudes towards the website and } \\
\text { the impact of attitudes on loyalty } \\
\text { are higher for Chinese customers } \\
\text { than for North Americans. }\end{array}$ \\
\hline $\begin{array}{l}\text { Stavrianea et } \\
\text { al. (2019) }\end{array}$ & $\begin{array}{l}\text { Examine gender } \\
\text { differences regarding EV } \\
\text { amongst Gen } \mathrm{Z} \text { members. }\end{array}$ & Online Booking & $\begin{array}{l}\text { Statistical differences were reported } \\
\text { regarding the } \mathrm{Pl} \text { and SE dimensions } \\
\text { of } \mathrm{EV} \text {. }\end{array}$ \\
\hline
\end{tabular}

Maintaining loyalty is a central business goal especially in a competitive environment such as tourism (Kavoura \& Stavrianea, 2016; Nam et al., 2011; Suhartanto et al., 2020). Patronage intentions relates to the customers' intention for positive word-of-mouth and preference of a service or product again in the future (Zeithaml, 1996). Prior research on the online shopping environments has also showed that EV could ameliorate customer satisfaction (Lee and Overby, 2004), as well as consumer attitudes towards the website and loyalty intentions (Brakus et al., 2009; Jeong et al., 2009; Mathwick et al., 2001; Shobeiri, 2018). Attitudes towards the OBP represent the overall evaluation of the OBP and how favourable this is for the consumer (Eagly \& Chaiken, 1993). A favourable evaluation, for example, can have an effect on patronage intentions. It is along these lines that this study proposes that EV can positively impact attitudes towards the OBP and behavioral intentions overall. Therefore, the research hypotheses have as follows: 
H1: EV from the OBP positively impact patronage intentions towards the OBP.

$H_{2}$ : EV from the $O B P$ positively impact attitudes towards the OBP.

$\mathrm{H}_{3}$ : Attitudes towards the OBP positively impact patronage intentions towards the OBP.

Furthermore, research has linked EV with website involvement (Shobeiri et al., 2014). Involvement with a website is a behavioral response and it can be perceived as the degree that the content of an OBP can hold the interest of the visitor (Shobeiri et al., 2014; Singh et al., 2005, p.289). Therefore, it is suggested that the offering of additional EV can contribute to consumer's interest in the OBP:

$\mathrm{H}_{4}$ : EV from the OBP positively impact the involvement with the OBP.

Online involvement has been shown to result in positive consumer responses such as patronage intentions (Shobeiri et al., 2014; Singh et al., 2005) for a website or an OBP by enhancing the interaction with consumers (Shobeiri et al., 2018). Therefore, we suggest that high involvement with the OBP positively impacts patronage intentions with the OBP:

$H_{5}$ : Involvement with the OBP positively impacts patronage intentions towards the OBP.

H6: Involvement with the OBP positively impacts attitudes towards the OBP.

The Conceptual Model of the study is shown in Figure 1.

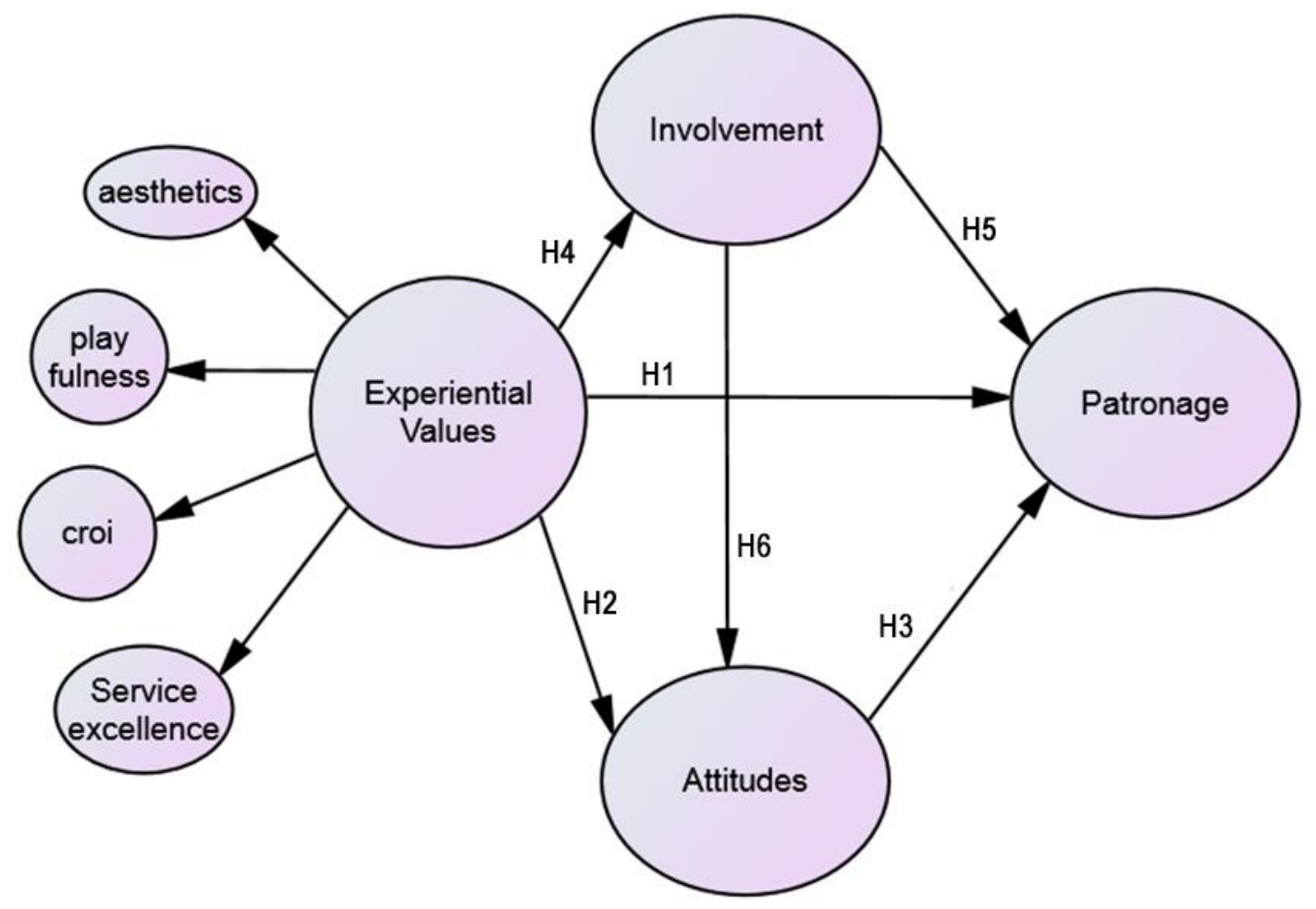

Figure 1. The Conceptual Model 


\section{Methodology}

This study has adopted a three-phase approach. Firstly, an extensive literature review informed the finalized questionnaire employed in the survey. The questionnaire was adopted from Shobeiri et al. (2018), where it was used for measuring EV, attitudes, involvement, and patronage intention for online shopping. Shobeiri et al.'s (2018) questionnaire was modified from the previous research of Mathwick et al. (2001), Eighmey (1997), Zeithaml et al. (1996), as well as Muehling et al. (1990). More precisely Shobeiri et al. (2018) also applied the Mathwick et al. (2001) experiential scale which contains the values of Aes, Pl, CROI, and SE in order to measure EV. Additionally, a 5-item construct was used to measure attitudes which was originally developed by Eighmey (1997), while the involvement construct was developed by Muehling et al. (1990). Finally, for patronage intentions, a construct with four items developed by Zeithaml et al. (1996) was used. The items examined were assessed with a 7-point Likert scale. Appendix 1 demonstrates the items of the study.

The second phase of the study included a pilot study of the questionnaire in a smaller scale to guarantee that the questionnaire distributed is functional and to ensure face validity (Kent, 1993). This was completed by 135 university students who responded to it after the completion of a teaching session, using their phone and providing researchers with the necessary feedback.

In the last phase, the quantitative research was conducted. The questionnaire was distributed solely online, and a non-probability sampling method (combination of criteria, convenience, and snowball sampling) was used, following Kamenidou et al. (2020b) procedure. The criterion for inclusion was that participants had to be members of the Greek Gen Z cohort (18-23 years old at the time of the research). At first, students of the researchers and acquaintances were requested to respond to the questionnaire via a link they could find on a Facebook page that was made for the specific research. Once opened, the link provided the user with the goals of the study, the participation criteria, and requested consent that the data could be used for research purposes (first question in the questionnaire), confirming to them confidentiality of the answers provided (Kamenidou et al., 2019).

Furthermore, respondents were asked to forward the link to relatives, friends and acquaintances who also belonged to Greek Gen Z cohort. The link could accept responses during a five-month period, i.e., August to December 2018. Via this data collection process, 970 responses were collected which were regarded as usable and suitable for analysis.

The subsequent analysis included: descriptive statistics, reliability analysis, discriminant validity, Confirmatory Factor Analysis (CFA) and SEM with AMOS.

\section{Results}

\section{Sample profile}

The sample consisted of 970 Gen Zers, of which $42 \%$ were males and $58 \%$ females, while $35 \%$ was $18-20$ years old and the rest $65 \%$ was $21-23$ years of age. Two main categories stood as education: $76 \%$ had up to postsecondary education, and $24 \%$ hold at least a bachelor's degree, while the vast majority $(63 \%)$ being university students and $19 \%$ being private employees. Lastly, $73 \%$ live in urban areas, while $27 \%$ live in rural areas, while as concerns net monthly family income $45 \%$ had an income up to $1000.00 €$, $24 \%$ had an income ranging from 1000.01-2000.00€ and $21 \%$ had an income more than $2000.00 €$.

\section{Reliability, Convergent, Discriminant Validity and CFA}

A second-order CFA was employed, and the results demonstrated a good fit for the measurement model and acceptable loadings for all items. Specifically, the Chi-Square test value was $32.848(\mathrm{df}=2)$ with 
p<0.001, while AGFI, TLI, CFI had values of o.919, 0.951, and 0.983, respectively. The measurement model was assessed for reliability, convergent and discriminant validity. All measurements had Cronbach's alpha higher than o.8o (Table 2) which indicates adequate internal consistency reliability (Nunnally, 1978).

Table 2. Cronbach's alpha

\begin{tabular}{ll}
\hline Parameter & Cronbach's alpha \\
\hline Aes & 0.90 \\
Pl & 0.92 \\
CROI & 0.90 \\
SE & 0.82 \\
Involvement & 0.95 \\
Attitudes & 0.96 \\
Patronage Intentions & 0.88 \\
\hline
\end{tabular}

The Average Variance Extracted (AVE) of all factors were observed to exceed o.70, above the threshold of 0.5 , and therefore, demonstrating convergent validity according to Fornell and Larcker (1981). To test for discriminant validity the square root of AVE of every factor was compared to all the correlations between factors. According to Fornell and Larcker (1981) discriminant validity was established, since the Square root of AVE was in each case higher than the correlations between factors (Table 3).

Table 3. Convergent and discriminant validity tests

\begin{tabular}{|c|c|c|c|c|c|c|c|c|}
\hline Factor & AVE & Aes & PL & $\mathrm{CRO}$ & SE & I & Attitude & PI \\
\hline Aes & 0.72 & 0.85 & & & & & & \\
\hline PL & 0.71 & 0.61 & 0.84 & & & & & \\
\hline CROI & 0.76 & 0.59 & 0.54 & 0.87 & & & & \\
\hline SE & 0.85 & 0.63 & 0.65 & 0.69 & 0.92 & & & \\
\hline I & 0.74 & 0.63 & 0.62 & 0.68 & 0.73 & 0.86 & & \\
\hline Attitude & 0.82 & 0.01 & 0.27 & 0.33 & 0.10 & 0.13 & 0.91 & \\
\hline PI & 0.72 & 0.58 & 0.33 & 0.59 & 0.57 & 0.66 & 0.25 & 0.85 \\
\hline
\end{tabular}

\section{Path Analysis and hypotheses testing}

The Structural Equation Model with AMOS 24 software package was employed to test the aforementioned hypotheses. The model showed a good fit, with the Chi-Square, AGFI, TLI, CFI, RMSEA having values of $81.168(\mathrm{df}=9) p<.001,0.926,0.954,0.98$, o.091 respectively ( Hu \& Bentler, 1991). The path coefficients are presented in Table 4 , where coefficients in all cases are significant $(p<0.05)$. The construct of EV positively impacts directly patronage intentions (0.57), attitudes towards the OBP (o.16) and customer involvement (o.85), providing strong support for hypotheses $\mathrm{H}_{1}, \mathrm{H}_{2}$, and $\mathrm{H}_{4}$. As expected, attitudes towards the OBP (o.o9) and involvement with the OBP (o.18) have positive direct effects on 
patronage intentions, providing support for the hypotheses $\mathrm{H}_{3}$ and $\mathrm{H}_{5}$. Contrary to the authors' expectations, involvement with the OBP has a strong direct-but a negative-effect on consumers' attitudes towards the OBP, therefore hypothesis $\mathrm{H} 6$ is not supported.

Table 4. Structural relationships

\begin{tabular}{|c|c|c|c|}
\hline Hypotheses & Path & $\begin{array}{l}\text { Path } \\
\text { coefficient }\end{array}$ & p-value \\
\hline Hi & $\begin{array}{l}\text { Experiential Values } \rightarrow \\
\text { Patronage Intentions }\end{array}$ & 0.57 & $\mathrm{p}<0.001$ \\
\hline $\mathrm{H}_{2}$ & $\begin{array}{l}\text { Experiential Values } \rightarrow \\
\text { Attitudes towards the platform }\end{array}$ & 0.16 & $\mathrm{p}<0.050$ \\
\hline $\mathrm{H}_{3}$ & $\begin{array}{l}\text { Attitudes towards the platform } \rightarrow \\
\text { Patronage Intentions }\end{array}$ & 0.09 & $\mathrm{p}<0.001$ \\
\hline $\mathrm{H}_{4}$ & $\begin{array}{l}\text { Experiential Values } \rightarrow \\
\text { Involvement }\end{array}$ & 0.85 & $\mathrm{p}<0.001$ \\
\hline $\mathrm{H}_{5}$ & $\begin{array}{l}\text { Involvement with the platform } \rightarrow \\
\text { Patronage Intentions }\end{array}$ & 0.18 & $\mathrm{p}<0.001$ \\
\hline H6 & $\begin{array}{l}\text { Involvement with the platform } \rightarrow \\
\text { Attitudes towards the platform }\end{array}$ & -0.27 & $\mathrm{p}<0.001$ \\
\hline
\end{tabular}

Figure 2 demonstrates the Structural Equation Model results.

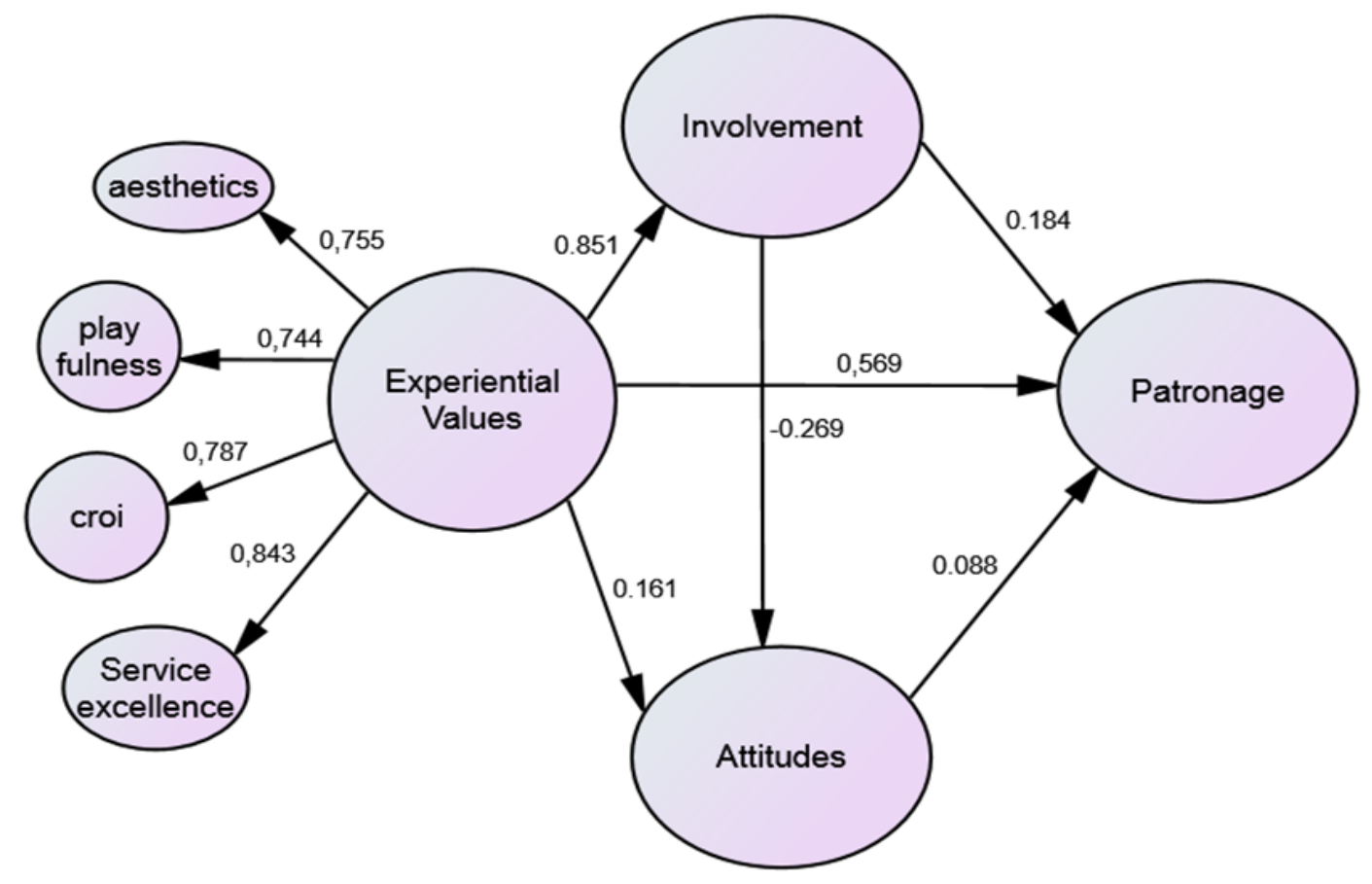

Figure 2. The Structural Model Results 


\section{Discussion and Conclusion}

This research provides important insights regarding the EV of Gen Zers towards OBP and their patronage intentions. Results revealed that offering value to the Gen $\mathrm{Z}$ cohort through additional experiences carries ultimately a very strong impact on their intention for positive future behaviour. The findings of the current research are aligned with prior research (e.g., Mohseni et al., 2014; Shobeiri et al., 2018) that explained the effect of EV on future intention, although-for the specific generational cohort and in the context of the OBP- the effect was even stronger. The EV nuance also plays a very significant role in capturing and maintaining this generational cohort's interest and involvement with the OBP. Again, it seems that for this young generational cohort the offering of additional experiences proves to be extremely important in order to get them engaged with the OBP. As anticipated, EV seem also to influence the Gen-Z cohorts' attitudes towards the OBP. Furthermore, involvement seems to constitute a key element that is related to patronage intentions, in accordance with prior research (Singh et al., 2005). The role of attitudes towards the OBP is also significant but less strong than the other factors examined in the formation of patronage intentions. Therefore, it becomes evident that the Gen $\mathrm{Z}$ cohort tourists highly appreciate the gaining of EV in order to get involved, have a positive attitude, and continue to patronage an OBP.

Furthermore, the research provides online travel services, tourism businesses and organizations with valuable information and practical suggestions from this research. Elements such as Aes, Pl, together with an overall SE are essential in order to achieve better performance for this cohort. Marketers in the tourism industry arena could take advantage of the results of the research since they offer insights on how to engage these young tourist-customers more with their products and services, and, consequently, repeat visits to their OBP. The latter is of greatest interest, particularly for this young, understudied generational cohort, who consist of the body of todays' as well as the near future's youngest adult consumers.

\section{Limitations and Directions for future research}

This current study is tied with several limitations that could constitute drivers for future research. Firstly, the research used a non-probability online data as a collection method, and as such, generalizability of results to the total Gen $\mathrm{Z}$ cohort is not realizable. Secondly, the targeted sample of the research consists merely of the Gen Z cohort and is thus limited to the age of 18-23 years old. Moreover, additional constructs may exist that can measure EV from OBP, but this study follows the research recommendations of Shobeiri et al. (2018).

Albeit its limitations identified, the contribution of the present study towards providing insights on tourism behaviour regarding the Gen $\mathrm{Z}$ cohort is valuable given that it is an increasingly evolving subject in the marketing field.

Undoubtedly, further research may incorporate a probability sampling method involving all Greek generational cohorts. Likewise, other future research pathways could embrace alternative dimensions to measure tourist EV in the tourisms' digital transformation era.

\section{References}

Ahn, J., Lee, C. K., Back, K. J., \& Schmitt, A. (2019). Brand experiential value for creating integrated resort customers' co-creation behavior. International journal of hospitality management, 81, 104-112.

Abdullah, D., Jayaraman , K., \& Kamal, S.B.M. (2016). A conceptual model of interactive hotel website: The role of perceived website interactivity and customer perceived value toward website revisit intention. Procedia Economics and Finance, 37, 170-175. 
Abou-Shouk, M. A., \& Khalifa, G. S. (2017). The influence of website quality dimensions on e-purchasing behaviour and e-loyalty: a comparative study of Egyptian travel agents and hotels. Journal of Travel $\mathcal{E}$ Tourism Marketing, 34(5), 6o8-623.

Alias, Z., Abdullah, M., Roslin, R.M., \& Shariff, S.H. (2016). Evaluating loyalty intention through the influence of servicescapes and shoppers' experiential values. In Pyeman, J., Wan Rashid, W., Hanif, A., Syed Mohamad, S., Tan, P. (eds) Proceedings of the 1st AAGBS International Conference on Business Management 2014 (AiCoBM 2014). Springer, Singapore, 343-354.

Bigné, E., Zanfardini, M., \& Andreu, L. (2020). How online reviews of destination responsibility influence tourists' evaluations: an exploratory study of mountain tourism. Journal of Sustainable Tourism, 28(5), 686-704.

Brakus, J. J., Schmitt, B. H., \& Zarantonello, L. (2009). Brand experience: What is it? How is it measured? Does it affect loyalty?". Journal of Marketing, 73(3), 52-68.

Buhalis, D. (1998). Strategic use of information technologies in the tourism industry. Tourism Management, 19(5), 409-421.

Buhalis, D., \& Amaranggana, A. (2013). Smart tourism destinations. In Xiang, Z., Tussyadiah, I. (eds.) (2013). Information and Communication Technologies in Tourism 2014, Cham: Springer, 553-564.

Buhalis, D., \& Law, R. (2008). Progress in information technology and tourism management: 20 years on and 10 years after the Internet-The state of eTourism research. Tourism Management, 29(4), 609-623.

Chatzigeorgiou, C., \& Christou, E. (2020). Adoption of social media as distribution channels in tourism marketing: A qualitative analysis of consumers' experiences. Journal of Tourism, Heritage E Services Marketing, 6(1), 25-32.

Chiappa, G., Sini, L., \& Atzeni, M. (2020). A motivation-based segmentation of Italian Airbnb users: an exploratory mixed method approach. European Journal of Tourism Research, 25, 1-20.

Choi, S. (2015). Understanding roles of experiential value and perceived switching drivers on travelers' loyalty: An empirical study of third-party travel websites (Doctoral dissertation, Kansas State University). URL: http://krex.k-state.edu/dspace/handle/2097/20412 (Accessed on 12.1.2019).

Cohen, S.A., Prayag, G., \& Moital, M. (2014). Consumer behaviour in tourism: Concepts, influences and opportunities. Current Issues in Tourism, 17(10), 872-909.

Dogru, T., Mody, M., Suess, C., McGinley, S., \& Line, N. D. (2020). The Airbnb paradox: Positive employment effects in the hospitality industry. Tourism Management, 77, 104001.

Eagly, A. H., \& Chaiken, S. (1993). The Psychology of Attitudes. 2nd ed. London: Harcourt Brace Jovanovich College Publishers.

Eighmey, J. (1997). Profiling user responses to commercial web sites. Journal of Advertising Research, 37(3), $59-66$.

Fan, X., Chai, Z., Deng, N., \& Dong, X. (2020). Adoption of augmented reality in online retailing and consumers' product attitude: A cognitive perspective. Journal of Retailing and Consumer Services, 53, 101986.

Fiore, A.M., Kim, J., \& Lee, H.H. (2005). Effect of image interactivity technology on consumer responses toward the online retailer. Journal of Interactive Marketing, 19(3), 38-53.

Fornell, C., \& Larcker. C. (1981). Evaluating structural equation models with unobservable variables and measurement error. Journal of Marketing Research, 18 (1), 39-50.

Gentile, C., Spiller, N., \& Noci, G. (2007). How to sustain the customer experience: An overview of experience components that co-create value with the customer. European Management Journal, 25(5), 395-410.

Gretzel, U., Sigala, M., Xiang, Z., \& Koo, C. (2015). Smart tourism: Foundations and developments. Electronic Markets, 25(3), 179-188. 
Guillet, B. D., Mattila, A., \& Gao, L. (2020). The effects of choice set size and information filtering mechanisms on online hotel booking. International Journal of Hospitality Management, 87, 102379.

Hallikainen, H., Alamäki, A., \& Laukkanen, T. (2019). Individual preferences of digital touchpoints: A latent class analysis. Journal of Retailing and Consumer Services, 50, 386-393.

Härting, R.C., Reichstein, C., Härtle, N., \& Stiefl, J. (2017). Potentials of digitization in the tourism industry-empirical results from German experts. In Abramowicz W. (eds) Proceedings of the International Conference on Business Information Systems, BIS (2017, June). Lecture Notes in Business Information Processing (LNBIP), 288. Cham: Springer, 165-178.

Hassannia, R., Vatankhah Barenji, A., Li, Z., \& Alipour, H. (2019). Web-Based recommendation system for smart tourism: Multiagent technology. Sustainability, 11(2), 323.

Henriette, E., Feki, M., \& Boughzala, I. (2016). Digital transformation challenges. Proceedings of the Mediterranean Conference on Information Systems (MCIS) 2016, 33.

Holbrook, M. B. (1994). The nature of customer value: An axiology of services in the consumption experience. In Jacoby, J. \& Olson, J.C. (Eds.), (1994). Service quality: How guests view stores and merchandise. Lexington, MA: Lexington Books, 21-71.

Holbrook, M. B. (2006). Consumption experience, customer value, and subjective personal introspection: An illustrative photographic essay. Journal of Business Research, 59(6), 714-725.

Hu, L. \& Bentler, P.M. (1995). Evaluating model fit. In Hoyle, R.H. (Ed.), Structural Equation Modelling: Concepts, Issues and Applications. Thousand Oaks, CA: Sage, 76-99.

Huang, H., Liu, S. Q., Kandampully, J., \& Bujisic, M. (2020). Consumer responses to scarcity appeals in online booking. Annals of Tourism Research, 8o, 102800.

Jeong, S.W., Fiore, A.M., Niehm, L.S., \& Lorenz, F.O. (2009). The role of experiential value in online shopping: the impacts of product presentation on consumer responses towards an apparel web site. Internet Research, 19(1),105-124.

Kamenidou, I. C., Mamalis, S. A., \& Pavlidis, S. (2019). Segmenting the generation z cohort university students based on sustainable food consumption behavior: A preliminary study. Sustainability, 11(3), 837.

Kamenidou, I.E., Stavrianea, A., Bara \& E.-Z. (2020a). Generational Differences toward Organic Food Behavior: Insights from Five Generational Cohorts. Sustainability, 12, 2299.

Kamenidou, I. E., Stavrianea, A., Mamalis, S., \& Mylona, I. (202ob). Knowledge Assessment of COVID19 Symptoms: Gender Differences and Communication Routes for the Generation Z Cohort. International Journal of Environmental Research and Public Health, 17(19), 6964.

Kamenidou, I.E.C., Mamalis, S.A., \& Dimitriadis, E. (2018). Generation Z perceptions of quality certification: A cross-national study. International Journal of Food and Beverage Manufacturing and Business Models (IJFBMBM), 3(1), 23-41.

Kavoura, A. \& Stavrianea, A. (2016). A brand experiences' conceptual model for visitors' attitudinal loyalty. TOURISMOS: An International Multidisciplinary Refereed Journal of Tourism, 11(4), 1-21.

Kayumovich, K. O. (2020). Prospects of digital tourism development. Economics, 1(44).

Keng, C.J., Huang, T.L., Zheng, L.J., \& Hsu, M.K. (2007). Modeling service encounters and customer experiential value in retailing. International Journal of Service Industry Management, 18(4), 349-367.

Kent, R. (1993). Marketing Research in Action. Routledge: London, UK.

Lam, C., \& Law, R. (2019). Readiness of upscale and luxury-branded hotels for digital transformation. International Journal of Hospitality Management, 79, 60-69.

Lee, E. J. (2005). Creating value for online shoppers: Implications for satisfaction and loyalty. AP - Asia Pacific Advances in Consumer Research, 6, 370.

Lee, E.J., \& Overby, J.W. (2004). Creating value for online shoppers: Implications for satisfaction and loyalty. Journal of Consumer Satisfaction, Dissatisfaction and Complaining Behavior, 17, 54-67. 
Lee, H., Chen, K. L., \& Yang, J. (2014). The implications of big data for the enterprise system for small businesses. Proceedings of DYNAA, 5(1), 38-42.

Li, L., Peng, M., Jiang, N., \& Law, R. (2017). An empirical study on the influence of economy hotel website quality on online booking intentions. International Journal of Hospitality Management, 63, 1-10.

Li, X., Zhao, X., \& Pu, W. (2020). Measuring ease of use of mobile applications in e-commerce retailing from the perspective of consumer online shopping behaviour patterns. Journal of Retailing and Consumer Services 55, 102093. https://doi.org/10.1016/j.jretconser.2020.102093.

Mano, H., \& Oliver, R.L. (1993). Assessing the dimensionality and structure of the consumption experience: Evaluation, feeling, and satisfaction. Journal of Consumer Research, 20(3), 451-66.

Manyiwa, S., Priporas, C. V., \& Wang, X. L. (2018). Influence of perceived city brand image on emotional attachment to the city. Journal of Place Management and Development, 11(1), 60-77.

Mathwick, C., Malhotra, N., \& Rigdon, E. (2001). Experiential value: Conceptualization, measurement, and application in the catalog and internet shopping environment. Journal of Retailing, 77(1), 39-56.

Mohseni, S., Jayashree, S., Rezaei, S., Kasim, A., \& Okumus, F. (2018). Attracting tourists to travel companies' websites: The structural relationship between website brand, personal value, shopping experience, perceived risk and purchase intention. Current Issues in Tourism, 21(6), 616-645.

Moutinho, L. (1987). Consumer behaviour in tourism. European Journal of Marketing, 21(10), 5-44.

Muehling, D.D., Stoltman, J.J., \& Grossbart, S. (1990). The impact of comparative advertising on levels of message involvement. Journal of Advertising, 19(4), 41-50.

Nam, J., Ekinci, Y., \& Whyatt, G. (2011). Brand equity, brand loyalty and consumer satisfaction. Annals of Tourism Research, 38(3), 1009-1030.

Nunnally, J.C. (1978). Psychometric theory. 2nd Edition, McGraw-Hill, New York.

Osei, B. A., Ragavan, N. A., \& Mensah, H. K. (2020). Prospects of the fourth industrial revolution for the hospitality industry: a literature review. Journal of Hospitality and Tourism Technology, Vol. aheadof-print No. ahead-of-print. https://doi.org/10.1108/JHTT-o8-2019-0107.

Pabel, A. (2020). Towards a better understanding of technology in tourism. Journal of Hospitality and Tourism Management, 42, 256-285.

Pantano, E., \& Priporas, C. V. (2016). The effect of mobile retailing on consumers' purchasing experiences: A dynamic perspective. Computers in Human Behavior, 61, 548-555.

Papathanassis, A. (2017). R-Tourism: Introducing the potential impact of robotics and service automation in tourism. Ovidius University Annals, Series Economic Sciences, 17(1), 211-216.

Pierdicca, R., Paolanti, M., \& Frontoni, E. (2019). eTourism: ICT and its role for tourism management. Journal of Hospitality and Tourism Technology, 10(1), 90-106.

Pine, B.J., \& Gilmore J.H. (1999). The Experience Economy. Boston: Harvard Business School Press.

Priporas, C. V., Stylos, N., Rahimi, R., \& Vedanthachari, L. N. (2017a). Unraveling the diverse nature of service quality in a sharing economy: A social exchange theory perspective of Airbnb accommodation. International Journal of Contemporary Hospitality Management, 29(9), 2279-2301.

Priporas, C. V., Stylos, N., Vedanthachari, L. N., \& Santiwatana, P. (2017b). Service quality, satisfaction, and customer loyalty in Airbnb accommodation in Thailand. International Journal of Tourism Research, 19(6), 693-704.

Priporas, C. V., Stylos, N., \& Fotiadis, A. K. (2017c). Generation Z consumers' expectations of interactions in smart retailing: A future agenda. Computers in Human Behavior, 77, 374-381.

Reinikainen, H., Kari, J. T., \& Luoma-Aho, V. (2020). Generation Z and organizational listening on social media. Media and Communication, 8(2), 185-196.

Ristova, C., \& Maglovski, A. (2018). Transforming hospitality in the digital era, factor for competitiveness in the tourist destination. Proceedings of the 7 th International Congress HOTELPLAN 2018, Book of Proceedings Zbornik Radova, 2-3 Nov 2018, Belgrade, Serbia. Hospitality as a Quality Factor of Tourist Destination Offer and Competitiveness, Book of Proceedings, 693-70o. 
Rose, S., Clark, M., Samouel, P., \& Hair, N. (2012). Online customer experience in e-retailing: an empirical model of antecedents and outcomes. Journal of Retailing, 88(2), 308-322.

Ruiz-Gómez, L. M., Navío-Marco, J., \& Rodríguez-Hevía, L. F. (2018). Dynamics of digital tourism’s consumers in the EU. Information Technology \& Tourism, 20(1-4), 59-81.

Saidon, J., \& Musa, R. (2017). Does digital experiential values affect digital engagement among yummies in m-commerce? Advanced Science Letters, 23(8), 7482-7485.

Sánchez-Lozano, G., Pereira, L., \& Chávez-Miranda, E. (2020). Exploring online prices with an advance booking horizon on Booking.com. European Journal of Tourism Research, 26, 2606.

Shobeiri, S., Laroche, M., \& Mazaheri, E. (2013). Shaping e-retailer's website personality: The importance of experiential marketing. Journal of Retailing and Consumer Services, 20(1), 102-110.

Shobeiri, S., Mazaheri, E., \& Laroche, M. (2014). Improving customer website involvement through experiential marketing. Service Industries Journal, 34 (11), 885-90o.

Shobeiri, S., Mazaheri, E., \& Laroche, M. (2015). Shopping online for goods vs. services: Where do experiential features help more? International Journal of Consumer Studies, 39(2), 172-179.

Shobeiri, S., Mazaheri, E., \& Laroche, M. (2018). Creating the right customer experience online: The influence of culture. Journal of Marketing Communications, 24(3), 270-290.

Singh, S. N., Dalal, N., \& Spears, N. (2005). Understanding web home page perception. European Journal of Information Systems, 14(3), 288-302.

Stavrianea, A., Kamenidou, I., \& Bara, EZ (2019). Gender differences in experiential values components in an online booking condition: Insights from generation $Z$. Proceedings of the 12TH Annual EUROMED Academy of Business (EMAB) Conference: Business Management Theories and Practices in a Dynamic Competitive Environment, In Vrontis, D., Weber, Y., Tsoukatos, E (Eds), pp. 1233-1245. EuroMed Press.

Stiakakis, E., \& Vlachopoulou, M. (2017). The impact of social media on travelers 2.o. Tourismos: An International Multidisciplinary Journal of Tourism, 12(3), 48-74.

Suhartanto, D., Brien, A., Primiana, I., Wibisono, N., \& Triyuni, N. N. (2020). Tourist loyalty in creative tourism: the role of experience quality, value, satisfaction, and motivation. Current Issues in Tourism, 23(7), 867-879.

Tilokskulchai, A., \& Soontayatron, S. (2017). Social media and mobile service on travel experiential values in aging tourists: A Conceptual review and perspective. In Dusit Thani College (Eds) Conference Proceedings GRACIOUS, Hospitality and Tourism International Conference 2017. 29 November-2 December 2017 Bangkok, Thailand, p.212-220.

Unger, L.S., \& Kernan, J.B. (1983). On the meaning of leisure: An investigation of some determinants of the subjective experience. Journal of Consumer Research, 9(4), 381-392.

Vaško, M., \& Abrhám, J. (2015). Issues of secure and sustainable e-tourism: Case of the Czech Republic. Journal of Security E Sustainability Issues, 5(2), 137-148.

Vendrell-Herrero, F., Bustinza, O. F., Parry, G., \& Georgantzis, N. (2017). Servitization, digitization and supply chain interdependency. Industrial Marketing Management, 6o, 69-81.

Verhoef, P.C., Lemon, K.N., Parasuraman, A., Roggeveen, A., Tsiros, M., \& Schlesinger, L.A. (2009). Customer experience creation: Determinants, dynamics and management strategies. Journal of Retailing, 85(1), 31-41.

Wan, C. B. (2018). Flourishing through smart tourism: Experience patterns for co-designing technologymediated traveler experiences. The Design Journal, 21(1), 163-172.

Williams, K.C. \& Page, R.A. (2011). Marketing to the generations. Journal of Behavioral Studies in Business, 3, 1-17.

Xiang, Z., Magnini, V.P., \& Fesenmaier, D.R. (2015). Information technology and consumer behavior in travel and tourism: Insights from travel planning using the internet. Journal of Retailing and Consumer Services, 22, 244-249. 
Zeithaml, V.A., Berry, L.L. \& Parasuraman, A. (1996). The behavioral consequences of service quality. Journal of Marketing, 6o, 31-46.

Zervas, G., Proserpio, D., \& Byers, J. W. (2017). The rise of the sharing economy: Estimating the impact of Airbnb on the hotel industry. Journal of Marketing Research, 54(5), 687-705.

Zhao, X., Wang, L., Guo, X., \& Law, R. (2015). The influence of online reviews to online hotel booking intentions. International Journal of Contemporary Hospitality Management, 27(6), 1343-1364.

Zsarnoczky, M. (2018). The Digital Future of the Tourism \& Hospitality Industry. Boston Hospitality. Boston University, School of Hospitality Administration. URL: http://www.bu.edu/bhr/files/2018/o6/The-Digital-Future-of-the-Tourism-and-HospitalityIndustry.pdf (Accessed on 12.1.2019).

Appendix 1: Constructs, items, and factor loadings

\begin{tabular}{ll}
\hline Items & $\begin{array}{l}\text { Loading on } \\
\text { EV }\end{array}$ \\
\hline Aesthetics (Aes)
\end{tabular}


Items

EV

Patronage intentions (PI)

I will recommend the OBP.

I will use the OBP in the future.

The OBP is my first choice for booking.
Loading on

factor

0.861

0.918

0.754

Received: 24/02/2019

Accepted: 19/04/2021

Coordinating editors: Maro Vlachopoulou and Konstantinos Fouskas 